креативно-прогностичній складовій інновачійної культури майбутнього керівника закладу загальної середньої освіти, передбачає створення ним принципово нових інтелектуальних і творчих освітніх продуктів та їх реалізацію чи впровадження в навчальний та управлінський прочес із урахуванням валеологічної складової інноваційної діяльності. Визначено рівні розвитку інновачійної культури майбутніх керівників закладів середньої освіти у процесі магістерської підготовки: гармонійний (високий), агрегативний (достатній), сумативний (низький).

Ключові слова: критеріально-оцінний інструментарій, критерій, показник, інноваційна культура, розвиток інноваційної культури, майбутній керівник, заклад загальної середньої освіти.

удк 371. 315: 811. 111 (043.5)

Ірина Корнєєва
Київський національний університет
технологій та дизайну
ORCID ID 0000-0003-4617-6741
$10.24139 / 2312-5993 / 2020.01 / 224-238$

\title{
МОНОЛОГ-ПРЕЗЕНТАЦІЯ ЯК ЕФЕКТИВНИЙ МЕТОД ІНШОМОВНОГО ПРОФЕСІЙНО ОРІЄНТОВАНОГО НАВЧАННЯ МАЙБУТНІХ ДИЗАЙНЕРІВ
}

У статті обгрунтовано метод презентацій, який нами визначається, як ефективний метод іншомовного професійно орієнтованого навчання майбутніх дизайнерів. Проаналізовано теоретичні передумови навчання методу презентацій, сучасний стан навчання іншомовній презентації в нелінгвістичних закладах вищої освіти України, ознаки методу презентації в організаційному процесі навчання майбутніх дизайнерів. Визначено поняття іншомовної презентації та надано зразки іншомовних презентацій майбутніх дизайнерів у монологічному мовленні (монолог-презентаціядоповідь, монолог-презентація-реклама). Доведено, що формування професійно орієнтованої англомовної компетентності майбутніх дизайнерів у застосуванні методу презентації є складним процесом, який містить метакомунікативний, структурний, лексико-граматичний, стилістичний і міжкультурний аспекти презентації.

Ключові слова: професійно орієнтоване навчання, метод презентацій, майбутні дизайнери, іншомовна презентація-доповідь, презентація-реклама, профресійно орієнтована англомовна компетентність, аспекти презентації, нелінгвістичні заклади вищої освіти України.

Постановка проблеми. Методи дослідження - це способи пізнання й вивчення явищ дійсності. У методиці навчання іноземних мов і культур вони мають на меті одержання даних про закономірності навчання іноземних мов і культур, про ефективність навчальних матеріалів, що використовуються, способів і форм навчально-виховного процесу (Ніколаєва, 2013, с. 45).

Вивчення й узагальнення позитивного досвіду роботи вчителів $\epsilon$ також надзвичайно важливим методом дослідження, тому що майстри педагогічної праці нерідко знаходять прийоми й методи рішення, використання яких значно підвищує ефективність навчального процесу (Ніколаєва, 2013, с. 46).

Організація навчання монологу-презентації багато в чому співпадає 3 організацією проєктної роботи. Метод проєктів був запропонований 
американським педагогом У. Кілпатріком на початку $X X$ сторіччя. Наприкінці 80-х років цей метод став актуальним для навчання IM як спосіб інтенсифікації учіння студентів. Проєктний метод досліджувався такими вченими-методистами, як К. Вудвард, Ч. Річардс, С. Горлицька, Е. Коллінгз, М. Нолла, Ю. Олькерс, Є. Полат, В. Стернберг, К. Черм та ін.

Ми поділяємо точку зору дослідників щодо завдань, які постають перед майбутніми фахівцями під час підготовки проєкту: 1) сформулювати проблему, вирішення якої потребує інтегрованого знання, дослідницького пошуку; 2) здійснити аналітичний огляд інформації з обраної теми й дійти висновків; 3) підготувати чітко структуровану доповідь; 4) розробити наочні матеріали, необхідні для презентації проєкту; 5) представити проєкт, залучаючи набуті навички проведення презентації IM і сучасні мультимедійні ресурси (Мельникова, 1999).

Ознаки проєктного методу співпадають з ознаками роботи над монологом-презентацією: 1) орієнтованість на дію; 2) робота в команді; 3) самоорганізація студентів; 4) ситуативна спрямованість, кореляція 3 реальним життя; 5) інтердисциплінарність (міжпредметні зв'язки), 6) цілісність; 7) орієнтованість на продукт, результат (Медведева, 2003).

М. О. Скуратівська виокремлює такі фази проєкту: 1) ініціювання винайдення ідеї проєкту; 2) початок проєкту; 3) проведення проєкту; 4) презентація результатів проєкту; 5) оцінка (рефлексія) проєкту (Корнєєва, 2019).

I. О. Деркач виокремлює більше етапів роботи над проєктом: 1) визначення теми проєкту; 2) визначення проблеми й мети проєкту; 3) обговорення структури проєкту, укладання приблизного плану роботи; 4) презентація необхідного мовного матеріалу й докомунікативна підготовка; 5) пошук інформації (робота з різноманітними джерелами, створення власної системи збереження інформації); 6) групова робота; 7) регулярні зустрічі, під час яких студенти обговорюють проміжні результати. Викладач виступає консультантом з мови, коментує виконану студентську роботу, виправляє помилки, проводить презентацію й опрацювання нового матеріалу; 8) аналіз зібраної інформації, координація дій різних груп студентів; 9) підготовка презентації проєкту - відеофільм, покази тощо; 10) демонстрація результатів проєкту (захист проєкту), опанування; 11) колективне обговорення проєкту, експертиза, результати зовнішньої оцінки, висновки (Корнєєва, 2019).

У підготовці монологу-презентації майбутніх дизайнерів ми виділяємо такі особливості: 1) підготовка монологу-презентації починається на 3-4-му курсах, коли студенти вже досягли рівня В2 відповідно до ЗЄР з мовної освіти; 2) тема монологу-презентації співпадає з темою, пропонованою робочою програмою з АМ, виучуваною протягом модуля; 3) тема використання IM наближена до реальних умов професійної діяльності дизайнерів; 4) мотивування студентів до самостійної роботи (індивідуальної / групової); 5) демонстрація результату 
роботи - підготовленого монологу-презентації за підтримки Інтернет технологій, програми M icrosoft Office PowerPoint.

Отже, за останні десять років багато вчених-методистів відкрили шлях професійно орієнтованого іншомовного навчання. Але, метод презентацій, як ефективний метод іншомовного професійно орієнтованого навчання майбутніх дизайнерів, $\epsilon$ теоретично та практично необгрунтованим, методично не розробленим.

Аналіз актуальних досліджень. Дослідження багатьох учених в останні десять років зосереджено на вирішенні проблеми навчання іншомовного презентаційного мовлення: досліджено історію розвитку презентаційного мовлення загалом (М. Гаспаров, А. Козаржевський, Н. Михальська, Г. Удалих) та іншомовного презентаційного мовлення зокрема (Дж. Вайссман, R. Adler, J. Billinham, J.Comfort, J.King, M. Powell, J.Ring). Останні дослідження вітчизняних методистів (О.В.Попель навчала майбутніх інженерів (Попель, 2015); Н. К. Лямзіна - майбутніх економістів (Лямзіна, 2015); Я. О. Дьячкова майбутніх правознавців (Дьячкова, 2015), безперечно, вдосконалюють методику навчання англомовного ділового професійного мовлення, зокрема розвитку вмінь інформування співрозмовників і переконання їх у необхідності підтримки ідей, викладених у презентаційних промовах. Досліджено такі презентаційні промови як англомовний монологпереконання (я. О. Дьячкова (Дьячкова, 2015), франкомовний монологаргументація (Л. В. Бондар (Бондар, 2012), англомовний монолог-бізнеспрезентація (Ю. С. Авсюкевич (Авсюкевич, 2009), німецькомовний монологпрезентація-доповідь (Н. Л. Драб (Драб, 2005).

Однак до теперішнього часу проблема навчання майбутніх дизайнерів монологічного мовлення, зокрема англомовної презентації (монологу-презентації), є науково недослідженою.

О. В. Москалюк виявила, що проблема породження й відтворення презентаційного монологічного висловлювання безпосередньо пов'язана $з$ проблемою взаємозв'язку внутрішнього й зовнішнього мовлення майбутніх фахівців. Внутрішнє мовлення розуміють як інтеріорізовану мовленнєву дію, яка реалізується в згорнутій редукованій формі. При цьому ступінь згорнутості внутрішнього мовлення змінюється від повного внутрішнього проговорювання до максимального скорочення, що визначає рівень досконалості зовнішнього мовлення. В процесі визначення задуму майбутнього монологічного висловлювання, відбору тематичної фахової інформації та створення на її основі первинного тексту внутрішнє мовлення студентів характеризується повним розгортанням через недостатність відповідних мовних і професійних знань і вмінь. У процесі аналізу та критичного осмислення змісту вибраної тематичної інформації й створення на їі основі вторинного тексту внутрішнє мовлення студентів частково скорочується, що забезпечує тренувальний виклад тексту промови в 
зовнішньому мовленні. Після засвоєння студентами вторинного тексту, введення до його змісту стилістичних засобів виразності внутрішнє мовлення майбутніх фахівців характеризується відносно повним рівнем згортання, що забезпечує готовність мовця до викладу усної промови перед аудиторією слухачів (Корнєєва, 2019).

Ми погоджуємося з О.В.Попель, яка стверджує, що ефективність навчання майбутніх фахівців англомовної презентації досягається за умови: 1) розгляду презентаційного мовлення у трьохвимірному форматі: як професійної грамотності, як риторичної спроможності, як іншомовномовленнєвої нормативності; 2) організації інтегрованого навчання, що передбачає набуття інтегрованих знань професійного й іншомовного матеріалу, формування інтегрованих навичок його вживання в риторикомовленнєвих діях, розвиток інтегрованих умінь викладу технічної інформації в її презентаційно-рекламній формі; 3) представлення професійної інформації в ії номінально-фактичному, оповідально-презентаційному, уточнювальнопрезентаційному, деталізовано-презентаційному, інтерактивнопрезентаційному та професійно-презентаційному вигляді (Попель, 2015).

Ми поділяємо точку зору О. В. Попель щодо обмеженого визначення презентаційного мовлення лише в його монологічній формі, яке показує недооцінку значення зворотного зв'язку з тими, до кого воно спрямоване, внаслідок чого призводить до браку розвитку його полілогічної форми реалізації. Крім того, процес навчання професійного презентаційного мовлення $\epsilon$ інтегрованим, що не акцентується в жодному зі згаданих досліджень, присвячених навчанню іншомовної презентації. А між тим саме такий процес навчання втілює необхідність вирішення як професійних (головних), так і англомовних мовленнєвих (допоміжних) завдань; тобто використання АМ як супроводу професійної діяльності, в тому числі й презентації (Попель, 2015).

Таким чином, іншомовне професійно орієнтоване монологічне мовлення (ММ), зокрема монолог-презентація, $є$ цільовим для формування в майбутніх дизайнерів на старших курсах навчання в бакалавраті.

Отже, мета статті - обґрунтування методу презентацій у професійно орієнтованому навчанні іноземних мов у нелінгвістичних закладах вищої освіти України (ЗВО України).

Завдання дослідження: 1) обґрунтувати професійно орієнтоване іншомовне навчання монологу-презентації в нелінгвістичних закладах вищої освіти України; 2) обґрунтувати застосування інноваційних освітніх технологій для вдосконалення процесу професійно орієнтованого іншомовного навчання майбутніх дизайнерів у ЗВО України.

Методи дослідження. Для досягнення мети, розв'язання поставлених завдань використано комплекс методів дослідження, серед яких теоретичні - теоретичний аналіз наукової літератури, підручників, 
навчальних програм, посібників, сайтів, фахових журналів та інших джерел інформації з методики навчання IM, психології, нейрофізіології, психолінгвістики й педагогіки за темою дослідження; аналіз мовних особливостей дискурсу дизайнерів для добирання навчальних матеріалів і укладання комплексів вправ; емпіричні - наукове спостереження за перебігом навчання професійно орієнтованого англомовного ММ із метою визначення ефективнішого варіанту методики навчання; опитування фахівців із дизайну задля обґрунтування критеріїв оцінювання якості професійно орієнтованого англомовного ММ; експериментальностатистичні - проведення експерименту для перевірки ефективності розробленої методики; статистична обробка даних експерименту з метою підтвердження ефективності запропонованої методики навчання.

Виклад основного матеріалу. Отже, формування в майбутніх дизайнерів іншомовної компетентності в ММ є складним багатофакторним психологічним процесом, пов'язаним з оперативною та довготривалою пам'яттю, мисленням і мовленнєвими механізмами.

Згідно 3 дослідженням фахівців, вимогам працедавців до функціональних знань відповідають лише $28 \%$ середньостатистичних випускників 3ВО. $41 \%$ респондентів зазначають недостатність сформованості практичних навичок ефективного монологу-презентації.

Монолог-презентація як вид іншомовного ММ вважається ефективним засобом подолання мовного бар'єру, розвитку коректності й перебігу мовлення, навчання формування зв'язного тексту.

Термін «презентація» походить з англійського "presentation" i витлумачується як прочес ознайомлення слухачів з якоюсь темою. Зазвичай це демонстрація, лекція / промова з метою поінформувати / переконати когось. Презентація містить три складники: промову доповідача; слайди; роздавальні матеріали.

В індустріальному дизайні презентація $\epsilon$ одним із найбільш важливих і вирішальних етапів виробничого циклу, який охоплює такі його етапи: 1) бріф - визначення цілей дизайну; 2) аналітика - аналіз визначених цілей; 3) дослідження - вивчення схожих дизайн-рішень; 4) специфікація - опис необхідних затрат для реалізації дизайн-рішення; 5) дизайн-рішення - концептуалізація та технічний опис реалізації визначеного дизайн-рішення, 6) презентація - презентація дизайну.

Задля визначення сутності терміну «презентація» в дизайні, детальніше зупинимося на змісті дизайну. Дизайн є творчим методом, процесом і результатом художньо-технічного проєктування промислових виробів, їхніх комплексів і систем, орієнтованим на досягнення найповнішої відповідності створюваних об'єктів і середовища утилітарним і естетичним потребам людини. 
Етимологію дизайну дослідив О. М. Яремчук. Слово «проектування» походить від слова "project" (англ.), яке, у свою чергу, походить від латинського дієслова "proicere" - буквально: «кинути щось вперед».

3 самого початку, коли в англійській мові було прийнято вживати слово "project", воно означало «план (креслення, схему, ескіз) чогонебудь», а не акт створення цього плану. Для вираження поняття «процес створення проєкту» в англійській мові використовується слово "design".

В англомовному енциклопедичному словнику "design" визначається як: іменник: 1) задум, план; 2) творчий проєкт; 3) креслення, ескіз, конструкція; 4) малюнок, візерунок; 5) дизайн, композиція; 6) твір мистецтва; дієслово: 1) задумувати, замишляти, мати намір, планувати; 2) складати план (схему); проектувати; конструювати; 3) креслити, займатись проектуванням; бути конструктором (дизайнером); 4) створювати малюнок (візерунок, фасон тощо).

За однією з версій слово «дизайн» стало загальновживаним у Європі в XVI столітті. Його вперше згадав у одній зі своїх робіт італієць К. В. Сквер. Італійське висловлювання "design intero" означало «народжена в художника й викликана Богом ідея»- концепцію витвору мистецтва.

Оксфордський словник простежує по роках, як історично складалося сучасне поняття «дизайн»: 1548 р. - «мета, інтенція»; 1588 «задуманий людиною план або схема чогось, що буде реалізовано, перший начерк майбутнього твору мистецтва»; 1593 - «план в розумі того, що буде зроблено»; 1638 - «план будівництва»; 1697 - «зробити попередній ескіз для конструювання чого-небудь». Як видно з цього переліку, словникове значення стає конкретнішим і, відповідно, вужчим. Водночас зміст діяльності, який визначається цим словом, навпаки, стає «розмитішим» (Корнєєва, 2019).

Філософ М. Хайдеггер назвав мистецтво дизайну «вмінням-бути-усвіті» (Рунге, 2006).

Людину-проєктувальника називають дизайнером, що також $\epsilon$ терміном, який використовується для людей, які професійно працюють в одній із спеціалізацій дизайну.

Сьогодні дизайн - це комплексна міждисциплінарна проєктнохудожня діяльність, яка інтегрує природно-наукові, технічні, гуманітарні знання, інженерне й художнє мислення та спрямована на формування на промисловій основі предметного світу в надзвичайно великій «зоні контакту» його з людиною в усіх без винятку сферах життєдіяльності.

Майбутній дизайнер в умовах професійно орієнтованого навчання в нелінгвістичному зВО повинен уміти проєктувати ситуації своєї майбутньої професійної діяльності. Відповідно, система формування в майбутніх дизайнерів професійно орієнтованої іншомовної компетентності, зокрема в ММ, має бути адаптована під сучасні умови 
створення, виробництва, промоутерства дизайн-продукту, а також під умови конкуренції фахівців на світовому ринку.

Це набуває особливого значення для студентів 3-4-го курсів. Старші курси бакалаврату розглядаються психологами й методистами (Б. Г. Ананьев, Л. Г. Городилова, І.В.Самойлюкевич та ін.) як перехідний і найважливіший етап у навчанні IM, як системостворювальний ланцюжок між загальною тематикою початкового етапу репродуктивних мовленнєвих дій до формування професійно орієнтованих навичок і вмінь вищого продуктивного рівня (Введнская, 2001; Бех, 1997; Божович, 1997). Науковці наполягають на тому, що усне ММ повинне займати чільне місце з-поміж складників іншомовної комунікативної компетентності.

Сучасна методика навчання IM виокремлює комунікативні функції ММ: 1) інформативну (повідомлення інформації про предмети / події навколишнього середовища, опис явищ, дій, стану); 2) впливову (спонукання до дії / попередження небажаної дії, переконання щодо (не)справедливості поглядів, думок, дій, переконань); 3) експресивну / емоційно-виразну (використання мовленнєвого спілкування для опису стану, в якому знаходиться мовець для зняття емоційного напруження); 4) розважальну (виступ людини на сцені / серед друзів для розваги слухачів); 5) ритуальнокультову (висловлювання під час ритуального обряду: виступ на ювілеї тощо).

3 мовної точки зору ММ характеризується а) структурною завершеністю речень; б) відносною повнотою висловлювання; в) розгорнутістю й різноструктурністю фраз; г) досить складним синтаксисом; д) зв'язністю, яка передбачає володіння мовними засобами міжфразового й понадфразового зв'язку.

За характером логіко-синтаксичних зв'язків виокремлюються такі функціональні типи монологу, типові для професійних ситуацій: опис, розповідь, повідомлення, оцінка, роздум і доказ як його різновид. Однак у бізнес-середовищі зустрічаються функціональні типи професійно спрямованого монологу, які опинилися поза увагою дослідників: інструкція, розпорядження, публічна промова.

Водночас для спілкування в галузі ділових відносин усе частіше використовується термін «ділова презентація», яка $\epsilon$ різновидом публічного виступу (Корнєєва, 2019).

О.Б.Тарнопольский і Ю.С. Авсюкевич дослідили англомовну презентацію та доцільно класифікували їі види, виходячи з таких критеріїв: 1) інтенція мовця (мета презентації); 2) приналежність учасників комунікативного акту до певного культурного соціуму; 3) ступінь залученості аудиторії до презентаційного процесу й тип зворотного зв'язку; 4) стиль спілкування; 5) кількість презентаторів; 6) кількісний склад аудиторії, умови демонстрації презентації; 7) засоби візуальної підтримки; способи представлення презентації (Авсюкевич, 2009). 
О. Б. Тарнопольский і Ю. С. Авсюкевич дослідили три складові «презентації»: 1) вступ (зав'язка, прелюдія, увертюра) - 20 \% загального обсягу монологу; 2) основна частина - 60 \%; 3) завершення (фінальна разв'язка) - $20 \%$ (Авсюкевич, 2009).

О. І. Назаренко витлумачує презентацію як доповідь, що містить інформацію про стан процесу в тій галузі, якій вона присвячена, з чітким формулюванням теми, оглядом ситуації, про яку йдеться, висновками з теми АМ. Техніка презентації $€$ вагомою комунікативною навичкою, якої необхідно навчати, оскільки вона вміщує не лише знання мови, але й уміння правильно добирати, обробляти й подавати інформацію, адаптувати ії до конкретної аудиторії, враховуючи її професійні, демографічні, соціальні, гендерні, етнічні, релігійні й культурні особливості та можливі міжкультурні розбіжності в сприйнятті інформації (Назаренко, 2009).

Н. Л. Драб визначає усну презентацію як підготовлене професійно спрямоване ММ, яке ґрунтується на результатах аналітичного дослідження певної економічної проблеми, має чітке структурно-композиційне оформлення й націлене на ефективне інформування, мотивування чи переконання певної аудиторії з урахуванням ії основних культурологічних і соціально-демографічних характеристик (Драб, 2005).

Залежно від професійно спрямованої комунікативної діяльності Н. Л. Драб виокремлює презентацію-доповідь і презентацію-рекламу. Різниця між ними полягає в комунікативному намірі: інформувати слухачів про стан бізнес-процесу $\epsilon$ презентацією-доповіддю; мотивувати й переконати слухачів про корисність бізнес-продукту - презентацією-рекламою.

Отже, усна презентація-доповідь передбачає підготовлену, публічну, професійно спрямовану індивідуальну промову, яка ґрунтується на результатах узагальнення фактичної бізнес-інформації, містить висновок щодо ії застосування, має чітке логіко-композиційне оформлення й націлена на інформування членів команди про професійну діяльність або оцінювання.

Усна презентація-реклама передбачає підготовлену, публічну, професійно спрямовану індивідуальну або командну промову, яка ґрунтується на результатах дослідження якості певного бізнес-продукту й визначення його потенційного споживача, має чітке логіко-композиційне оформлення й націлена на мотивування або переконання клієнтів щодо його корисності.

Ми поділяємо точку зору Н. Л. Драб стосовно визначень презентаціїдоповіді й презентації-реклами та вважаємо доцільним упровадження цих видів монологічних висловлювань на 3-4-му курсах навчання майбутніх дизайнерів IM професійного спрямування, оскільки ці види монологу відповідають потребам професійної діяльності дизайнерів.

Ґрунтуючись на вище зазначену низку досліджень нами запропоновано визначення поняття «монологу-презентації» майбутніх дизайнерів як чітко підготовлену предметну промову фахівця, націлену 
на надання фрахової інформації, переконання, підсилення партнерської прихильності й умотивування слухача / аудиторії слухачів на сумісну дію (підпис контрактів; підготовка шоу, виставок, ярмарок; ведення гнучкої бізнес політики; промоутерство сервісу / продукту на світовий ринок) з додаванням безумовного доказу невербальними засобами, а також за допомогою Інтернет технологій

Проведений нами аналіз досліджень із лінгвістики (Корнєєва, 2019) підтверджує висновок щодо визначення ділової презентації як жанру ділового дискурсу. Наведемо приклади презентації-доповіді й презентаціїреклами.

\section{Зразок презентації-доповіді}

The "earth architecture" becomes the current trends in modern world architecture. It is designed not only to solve the main problem of the formation of the landscape but to find a reasonable balance between living and nonliving spheres. According to this, industrial methods of gardening in the cities of the world are focused primarily on the landscaping of the city and the salvation of the soil from degradation, because the issue of cleanliness of air and water in the largest world cities will never lose its relevance. In addition, Kyiv is one of the cities where a problem of rehabilitation and improvement of conditions of the inhabitants of the capital city is particularly acute. In addition, the quality of the urban environment is always in the background when the explosive pace of construction and socially unjustified decisions about greenery are truthful.

The issue of creating the comfortable environment through integrated environmentally acceptable quality control mechanisms is involved into a new branch of municipal economy - industry landscape. As part of the development programs of the new branch, the All-Ukrainian Congress of Professionals in Landscape Industry is planned. The general partner of the Congress of Ukrainian economic landscape and ecology professionals, "Landscape Industry and Service a new quality of life in the urban environment" is a "Lodge Landscape" Company.

In addition, the company "Lodge Landscape" occurs now as the most environmental aspects and quality of life concerned one in the capital. In fact, scientific and practical activities of gardening and landscaping in Kyiv have been allowed to put into practice with the most complex projects and efficient solutions, taking into account the landscape, environmental and social aspects of the urban environment.

\section{Зразок презентації-реклами}

To provide their employees with quality protective clothing is a legal and moral responsibility of the heads of oil and gas, energy and metallurgical companies. In particular, the staff of oil companies, energy and metallurgical industries operates in conditions of high risk of accident and receiving thermal burns. M oreover, there is always a risk of leakage of hazardous gases under high pressure, and the smallest spark can be a threat to human's life. One of the 
prerequisites for safe operation is the reliable protection of the personnel against electric arcs, open flames and splash of liquid metal using special clothing.

FIRSTEX Company is the exclusive representative of the American concern WESTEX - a recognized leader in the manufacture of fire-resistant cotton and blended fabrics for special clothing. In addition, experience in the production of high-quality fire-retardant textiles of world-famous concern WESTEX, has nearly 90 years. In addition, WESTEX INC. has the most modern equipment and qualified personnel - quality of the materials is constantly developed through innovative research and new technologies. At the same time, the main task of FIRSTEX - the country's market promotion of fire-resistant fabrics that provides optimal balance of high protective properties, comfort and price.

Taking this into account, the FIRSTEX Company is aimed at a long-term and mutually beneficial cooperation with customers, and guarantees high quality of delivered production, stability and predictability. Moreover, health and human's life - the highest value, so it is particularly important for safety standards and quality of work clothes in the gas, oil and metallurgical industries.

Отже, формування в майбутніх дизайнерів професійно орієнтованої англомовної компетентності у $\mathrm{MM}$, зокрема монолозі-презентації, $\epsilon$ складним процесом, який містить метакомунікативний, структурний, лексико-граматичний, стилістичний і міжкультурний аспекти презентації. Формування ділового англомовного дискурсу ми визначаємо як сукупність мовленнєвих і мовних засобів, які застосовуються з метою комунікації між майбутніми фахівцями певної професійної діяльності, які виконують комунікативні функції (інформативну, впливову, експресивну, розважальну, ритуально-культову) та ґрунтуються на специфічних дидактичних і методичних принципах навчання IM (урахування індивідуальних стилів навчання, групової взаємодії, вікових особливостей студентів 3-4-го курсів навчання, взаємозв'язку різних видів мовленнєвої діяльності (читання, письма, говоріння, аудіювання), професіоналізації тощо.

Узагальнену структуру презентації, зокрема в галузі індустріального дизайну (Industrial Design), ми розглядаємо в контексті об'єктноорієнтованого підходу як складну систему у вигляді тріади множин $A B C$ (рис. 1): множина А - множина об'єктів презентації, множина В - множина процесів презентації, множина С - множина об'єктів зовнішнього середовища.

Монолог-презентація у сфері дизайну, зокрема індустріального дизайну (Industrial Design) - не просто певний етап у професійній діяльності дизайнера, а черговий процес у промисловому циклі, метою якого $\epsilon$ переконання партнера / клієнта / інвестора в ефективності використання продукту / послуги / товару, в його першокласних якостях (відповідає потребам ринку / споживача; зручність; користь і краса; простота застосування; серійність; транспортування; упаковка тощо); сприяння 
просуванню продукту / товару / послуг на ринку; мотивація та стимуляція партнера / клієнта / інвестора до необхідних дій.

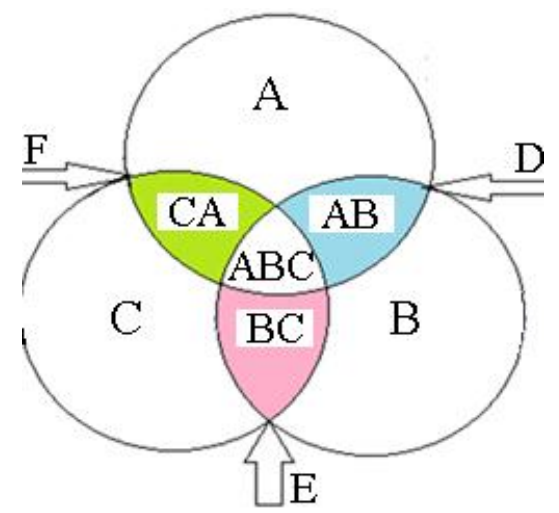

Рис. 1. Узагальнена структура презентації в контексті об'єктнооріентованого підходу до формування ПОАК у сфері індустріального дизайну

Монолог-презентація дизайнера - вид професійної діяльності, який інтегрує природно-наукові, технічні, гуманітарні знання, інженерне й художнє мислення, а також знання дискурсу, зокрема правил його побудови, знання мовних норм, лінгвосоціокультурні знання.

Презентація є потужним рекламним інструментом, який вимагає відповідних знань. Сам текст презентації повинен вирішувати такі завдання: розповісти, що просувається; розповісти, як товар (виріб) вирішує проблеми споживача; розповісти, де про товар можна дізнатися докладніше; справити враження й запам'ятатись.

На рис. 1 наведено такі зовнішні фактори особливостей успішної презентації:

D - поєднання графіки, тексту та анімації презентації. Часто для сильнішого ефекту презентація створюється спільно дизайнером і копірайтером. У такому випадку графіка стає пріоритетною, оскільки візуально людина спочатку аналізує графічну складову, а потім сприймає текст. І, тим не менш, обидва напрями формують кінцеве враження слухача про продукт. Графіка створює потрібну атмосферу та привертає увагу, а зміст дискурсу надає потрібну інформацію. Вкрай важливо, щоб графіка й текст доповнювали один одного й були одним цілим. I, незважаючи на те, що це поєднання є предметом вивчення іншої галузі знань - юзабіліті, копірайтерові слід пам'ятати, що погана графіка часто стає причиною неефективності хорошого тексту, лише тому, що слухач не звернув на нього увагу.

E - зручність сприйняття й запам'ятовуваність презентації. Презентація повинна сприйматися легко: Вона не має напружувати аудиторію й нав'язуватися їй. Тому рекомендується використовувати просту мову опису й мінімум деталей, який, однак, повинен бути достатнім, щоб сформувати уявлення у свідомості слухача про те, що 
просувається. Надлишок інформації може заплутати аудиторію, тому текст презентації має бути простим, доступним і зручним для сприйняття. Чим простішим $€$ текст презентації, тим краще він запам'ятовується. Навіть якщо слухач і не є покупцем, він може порекомендувати товар своїм знайомим, які можуть бути в ньому зацікавлені. Тому необхідно дати аудиторії можливість запам'ятати те, що просувається.

F - особисте враження від актуальності теми та презентації в цілому. Саме презентація націлена створити сприятливе враження на слухача, i чим сильніше - тим краще. Закономірність украй проста: коли на слухача справляється враження, він набагато краще запам'ятовує те, що йому пропонується, і йому набагато простіше купити те, в чому його переконали.

Рекомендації щодо посилення впливу монологу-презентації на аудиторію слухачів:

1. Будьте оригінальними (уникайте банальностей).

2. Будьте простими та здатними до викладання графічного й текстового матеріалу (наголосіть на створенні враження й максимальному запам'ятовуванні товару / бренду).

3. Позиціонуйте свій продукт (наприклад, коли тільки починалося виробництво нетбуків, виробники ASUS відразу позиціонували свій товар, зазначивши для нього нішу мобільних пристроїв $з$ різноманіття підключень до Інтернету. Як результат, нетбуки набули величезної популярності).

4. Уникайте найвищого ступеня (скажіть, чому Ваш товар є одним із кращих, у чому його цінність для споживача).

5. По змозі використовуйте легкий гумор, який $€$ дивовижним інструментом поліпшення гумору аудиторії та привертає увагу до Вашого дискурсу.

6. Не забувайте про зиск для споживача (які з їхніх проблем вирішаться, в який спосіб і чому? Чим більше переваг - тим вищим є ефект Вашої презентації).

7. Не забувайте про невербальні засоби презентації (жести й рухи). Якісні ілюструючі жести допоможуть Вам зробити презентацію яскравішою й переконливішою. Відточені жести, підкреслюючи зміст, надають Вам упевненості, й допомагають аудиторії сприйняти інформацію. Головне, щоб жести відповідали словам, адже аудиторія вірить мові тіла більше, ніж вербальному повідомленню.

Ось приклади невідповідності жестів словам: рука опускається на словах «За останній рік значно зросли доходи», широко розведені долоні під час промовляння фрази «Вкладення будуть невеликими»; «Любі жінки (жест убік чоловіків) і панове (помах убік жінок)».

Пам'ятайте також про те, що широта жестів і пересувань створює відчуття впевненості. Прийдіть на місце Презентації заздалегідь, 
призвичайтесь до цього простору, Ви можете його зробити своїм, скажіть пару фраз, пожестикулюйте, ввімкніть мікрофон, перевірте, як працює проектор. Це заспокоїть Вас і додасть Вам упевненості.

Отже, сучасний дизайнер у своїй професійній діяльності, зокрема проведенні іншомовної презентації, повинен інтегровано володіти професійно-предметними й іншомовними знаннями, навичками й уміннями, професійними мотивами й емоційно-вольовими якостями, сформованими внаслідок отримання досвіду оперативного вирішення завдань у контексті й логіці технологічних процесів професійної діяльності, а, відтак, і професійною компетентністю (Корнєєва, 2019).

Висновки та перспективи подальших наукових розвідок. Навчання монологу-презентації, як ми доводимо в нашому дослідженні, $\epsilon$ ефективним методом професійно орієнтованого іншомовного навчання майбутніх дизайнерів.

Інтегроване застосування методу презентацій у професійно орієнтованому іншомовному навчанні майбутніх дизайнерів у нелінгвістичних закладах вищої освіти України $\epsilon$ необхідною умовою модернізації змісту та структури професійної підготовки як цілісного, системного процесу. Метод презентацій у навчанні іноземних мов системне, комплексне застосування інноваційних освітніх технологій та інноваційних технологій комунікації світу. Перспективи вбачаємо в навчанні іншомовних презентацій будь-яких інших спеціальностей будьякою іноземною мовою в будь-яких ЗВО України.

\section{ЛІТЕРАТУРА}

Авсюкевич, Ю.С. (2009). Методика навчання презентації англійською мовою студентів економічних спеціальностей (дис. ... канд. пед. наук: 13.00.02). Київ. (Avsiukevich, J. S. (2009). M ethodic of the English language presentation training of the economic specialty students (PhD thesis). Kyiv.

Бех, І. Д. (1997). Духовні цінності в розвитку особистості. Педагогіка й психологія, 1, 123-129. (Beh, I. D. (1997). Soul values in individual development. Pedagogics and psychology, 1, 123-129).

Божович, Л.И. (1997). Проблемы формирования личности. Москва: Издательство «Институт практической психологии». (Bozhovich, L. I. (1997). The problems of personal development. M oscow: The Institute of the practical psychology).

Бондар, Л.В. (2012). Методика навчання французького професійно спрямованого монологічного мовлення студентів технічних спечіальностей з урахуванням їх навчальних стилів (автореф. дис. ... канд. пед. наук: 13.00.02). Київ. (Bondar, L. V. (2012). Methodic of the French language professional directed training of the monologue utterance of the technical specialty students with the coincidence of their training styles (DSc thesis abstract). Kyiv.

Введенская, Л. А., \& Павлова, Л. Г. (2001). Деловая риторика. Ростов-на-Дону: «МарТ». (Vvedenska, L. A., Pavlova, I. G. (2001). The business rhetoric. Rostov-on-Done).

Драб, Н.Л. (2005). Навчання майбутніх економістів іншомовного профресійно спрямованого монологічного мовлення (монологу-презентації німецькою 
мовою) (дис. ... канд. пед. наук: 13.00.02). Київ. (Drab, N. L. (2005). The future economists training of the foreign language professional directed monologue utterance (monologue-presentation in the German language) (PhD thesis). Kyiv.

Дьячкова, Я.О. (2015). Формування професійно спрямованої англомовної компетентності в говорінні у майбутніх правознавців (автореф. дис. ... канд. пед. наук: 13.00.02). Київ. (Dyachkova, Y. О. (2015). The forming of the professional directed the English language competence in the future lowers speaking) (DSc thesis abstract). Kyiv.

Корнєєва, І. О. (2019). Формування професійно орієнтованої англомовної компетентності в монологічному мовленні майбутніх дизайнерів (дис. ... канд. пед. наук: 13.00.02). Київ. (Korneyeva, I. O. (2019). The professional orientation the English language competence formation in the future designers monologue utterance) (PhD thesis). Kyiv.

Лямзіна, Н. К. (2015). Методика навчання майбутніх економістів профресійно орієнтованого монологічного мовлення з використанням веб-квесту (автореферат дис. ... канд. пед. наук). Одеса. (Liamzina, N. K. (2015). M ethodic of the future economists professional oriented monologue utterance training with webquest adopting) (DSc thesis abstract). Odessa.

Медведева, Е.В. (2003). Рекламная коммуникация. Москва: Едиториал уРсС. (M edvedeva, E. V. (2003). The advertisement communication. M oscow).

Мельникова, С. В. (1999). Деловая риторика (речевая культура делового общения) Ульяновск: УлгтУ. (M elnikova, S. V. (1999). The business rhetoric. Ulianovsk).

Назаренко, О. І. (2009). Мультимедійна презентація як ефективний спосіб інтегрування чотирьох мовленнєвих умінь у навчанні англійської мови для професійного спрямування. Вісник національного технічного університету України «КПІ». Філософія. Психологія. Педагогіка, 1 (25), 56-77 (Nasarenko, O. I. (2009). The multimedia presentation as an effective way of four speaking skills integration in the professional direction English language training. Visnyk of the national technical university of Ukraine "KPI". Philosophy. Psychology. Pedagogics, 1(25), 56-77).

Ніколаєва, С. Ю., Бориско, Н. Ф., Бігич, О.Б. (2013). Методика навчання іноземних мов $і$ культур: теорія і практика. Київ: Ленвіт. (Nikolaeva, S. U., Borisko, N. F., Bigych, O. B. (2013). M ethodic of foreign languages and cultures training: theory and practice. Kyiv).

Попель, О.В. (2015). Методика навчання майбутніх інженерів англомовної презентації технічного обладнання (автореф. дис. ... канд. пед. наук). Одеса. (Popel, O. V. (2015). Methodic of future engineers English language training of the technical equipment presentation) (DSc thesis abstract). Odessa.

Рунге, В. Ф. (2006). История дизайна, науки и техники (Кн. 1). Москва: Архитектура-С. (Runge, V. F. (2006). The history of design, science and technics. Moscow: Architecture-C).

\section{PEЗЮME}

Корнеева Ирина. Монолог-презентация как эффективный метод иноязычного профессионально ориентированного обучения будущих дизайнеров.

В статье обоснован метод презентаций, который нами определяется как эффрективный метод иноязычного профессионально ориентированного обучения будущих дизайнеров. Проанализированы теоретические предпосылки обучения методу презентаций, современное состояние обучения иноязычных презентаций в нелингвистических заведениях высшего образования Украины, признаки метода презентации в процессе организации обучения будущих дизайнеров. Определено 
понятие иноязычной презентации будущих дизайнеров в монологическом говорении (презентации-докладе, презентации-рекламе). Доказано, что фрормирование у будущих дизайнеров профессионально ориентированной англоязычной компетентности при применении метода презентации, - это сложный процесс, который состоит из метакоммуникативного, структурного, лексикограмматического и межкультурного аспектов презентации.

Ключевые слова: профрессионально ориентированное обучение, метод презентаций, будущие дизайнеры, иноязычная презентация-доклад, иноязычная презентация-реклама, профессионально ориентированная англоязычная компетентность, аспекты презентации, нелингвистические заведения высшего образования Украины.

\section{SUMMARY}

Komeyeva Irene Monologue-presentation as an effective method of foreign language professionally orientated teaching of future designers.

Introduction. In this article the presentation method is grounded. It is defined as an effective method of foreign language professionally oriented teaching of future designers. Some definite features of the presentation method are mentioned, among them: 1) orientation on action; 2) command work; 3) self-organization of the students; 4) situation orientation and coincidence with the real life; 5) discipline connection; 6) unification; 7) resulted aim.

The purpose of the article consists of the presentation method grounded on the foreign language professionally oriented teaching at nonlinguistic higher education institutions of Ukraine.

The research methods are used in order to solve the set tasks. They are: theoretical analysis of the scientific literature, training text-books, training programs, professional magazines and other information resources on the foreign languages methodology; empiric research - scientific moderation on foreign language professionally oriented teaching; questionnaire of future designers; experimental-statistics - experiment holding for effectiveness of methodologic results proof; statistic making of the experiment data.

The results of the research include the analysis of the theoretical conditions of the presentation method training, analysis of the modern state of the foreign language presentation training at nonlinguistic higher institutions of Ukraine. The features of presentation method in the organization process of future designers in monologuepresentation-report, monologue-presentation-advertisement are noted. The definition of the foreign language presentation is done. The article presents the examples of the presentations of designers (presentation-report, presentation-advertisement.

Conclusion. In the article we have proved that integration implementation of the presentation method in the foreign language professionally oriented teaching of future designers at nonlinguistic higher education institutions of Ukraine is the necessary condition of content and professional training structure modernization in purposeful and systematic process.

The perspectives are seen in foreign language monologue-presentation training of any other specifications of any other higher education institutions of Ukraine.

Key words: professionally oriented teaching, presentation method, future designers, foreign-language-presentation-report, foreign-language-presentation-advertisement, professionally oriented foreign language competence, presentation aspects, nonlinguistic higher education institutions of Ukraine. 